\title{
PENGARUH METODE PROYEK BERBASIS PENDEKATAN SAINTIFIK TERHADAP KECERDASAN INTERPERSONAL ANAK KELOMPOK B TK GUGUS I SUKAWATI
}

\author{
Putu Diana Agustin Suardana Putri ${ }^{1}$, Luh Ayu Tirtayani ${ }^{2}$, I Nengah Suadnyana ${ }^{3}$ \\ 1,2,3Jurusan Pendidikan Dasar \\ Universitas Pendidikan Ganesha \\ Singaraja, Indonesia \\ e-mail: dhianhaagusthin@gmail.com ${ }^{1}$, ayu.tirtayani@undiksha.ac.id ${ }^{2}$, \\ inengah.suadnyana@undiksha.ac.id ${ }^{3}$
}

\begin{abstract}
Abstrak
Penelitian ini bertujuan untuk mengetahui pengaruh metode proyek berbasis pendekatan saintifik terhadap kecerdasan interpersonal anak kelompok B TK Gugus I Sukawati Tahun Ajaran 2018/2019. Penelitian ini merupakan penelitian eksperimen semu (quasi eksperimen) dengan nonequivalent control group design. Populasi dalam penelitian ini adalah seluruh kelompok B TK Gugus I Sukawati yang memiliki jumlah kelas sebanyak 17, dan berjumlah 457 anak. Sampel penelitian ditentukan dengan teknik random sampling, sehingga diperoleh kelompok B2 TK Ana Kumara (28 peserta didik) sebagai kelompok eksperimen dan kelompok B1 TK Kumara Shanti Guwang (27 peserta didik) sebagai kelompok kontrol. Data kecerdasan interpersonal dikumpulkan menggunakan teknik non-tes berupa observasi dengan lembar observasi, kemudian data yang diperoleh dianalisis dengan uji-t. Hasil analisis penelitian ini menunjukkan nilai rata-rata kelompok eksperimen $(84,31)$ lebih tinggi daripada nilai rata-rata kelompok kontrol $(71,84)$. Berdasarkan hasil analisis uji-t dengan $\mathrm{dk}=53$ dan taraf signifikansi $=5 \%$, diperoleh thitung $>t_{\text {tabel }}(5,97>2,000)$ maka $\mathrm{H}_{\circ}$ ditolak, berarti terdapat perbedaan yang signifikan kecerdasan interpersonal anak kelompok eksperimen dengan kelompok kontrol. Dalam penelitian ini peningkatan kecerdasan interpersonal anak diukur pada kemampuan anak dalam bekerjasama, berempati, kepekaan dan pemahaman sosial, serta komunikasi sosial. Berdasarkan hasil tersebut, dapat disimpulkan bahwa metode proyek berbasis pendekatan saintifik berpengaruh terhadap kecerdasan interpersonal anak kelompok B TK Gugus I Sukawati Tahun Ajaran 2018/2019.
\end{abstract}

Kata-kata kunci: Metode proyek, pendekatan saintifik, kecerdasan interpersonal, anak usia dini.

\begin{abstract}
This study aims to determine the effect of the project method based on the scientific approach to interpersonal intelligence in children in group B TK Gugus I Sukawati Academic Year 2018/2019. This research is a quasiexperimental study with nonequivalent control group design. The population in this study were all groups B TK Gugus I Sukawati who had a total class of 17 , and numbered 457 children. The research sample was determined by random sampling technique, so that it obtained B2 group Ana Kumara (28 students) as the experimental group and B1 TK Kumara Shanti Guwang group (27 students) as the control group. Interpersonal intelligence data was collected using non-test techniques in the form of observations with observation sheets, then the data obtained were analyzed by t-test. The results of the analysis of this study showed that the average value of the experimental group (84.31) was higher than the average value of the control group (71.84). Based on the results of the t-test analysis with $\mathrm{dk}=53$ and significance level $=5 \%$, obtained tcount> ttable $(5.97>2,000)$ then $\mathrm{Ho}$ is rejected, meaning there is a significant difference in interpersonal intelligence of the experimental group with the control group. In this study the increase in interpersonal intelligence of children was measured in the ability of children to cooperate, empathize, sensitivity and social understanding, and social communication. Based on these results, it can be concluded that the project method based on the scientific approach influences the interpersonal intelligence of children in group B TK Gugus I Sukawati Academic Year 2018/2019.
\end{abstract}

Keywords : Project method, scientific approach, interpersonal intelligence, early childhoo 


\section{PENDAHULUAN}

Pendidikan merupakan proses merubah sikap dan tata laku seseorang atau kelompok orang, melalui upaya pengajaran dan pelatihan yang sesuai dengan prosedur pendidikan itu sendiri. Pendidikan haruslah dimulai sejak dini karena pada usia dini, anak mengalami perkembangan yang sangat pesat. Usia nol sampai enam tahun merupakan periode keemasan (golden age) dimana pada usia ini sangat menentukan dalam pembentukkan karakter, kecerdasan, dan kepribadian seorang anak.

Pendidikan Anak Usia Dini (PAUD) merupakan salah satu bentuk pendidikan yang menitikberatkan pada peletakan dasar kearah pertumbuhan dan perkembangan anak (Lestari, 2017). Pendidikan anak usia dini dilakukan melalui pemberian pengalaman, stimulasi yang maksimal atau rangsangan. Pemberian rangsangan pendidikan untuk anak usia dini dapat dilakukan dengan cara bermain serta bereksplorasi secara langsung. Mengingat dunia anak adalah dunia bermain, melalui bermain anak memperoleh pembelajaran yang mengandung aspek perkembangan kognitif, bahasa, sosial emosional, moral, dan fisik motorik (Nurjannah, 2017) Aspek perkembangan tersebut tidak berkembang dengan sendirinya, melainkan saling berintegrasi dan saling terjalin satu sama lainnya. Berdasarkan beberapa aspek perkembangan tersebut, salah satu aspek yang penting untuk dikembangkan sebagai bekal dalam hidup di lingkungan sosial masyarakat adalah aspek sosial emosional. Setiap anak perlu memiliki keterampilan sosial dan kemampuan mengolah emosi yang baik untuk membangun hubungan yang seimbang di lingkungan sosial dengan beragam perbedaan. Keterampilan sosial meliputi kemampuan anak untuk mengenal diri, mengendalikan emosi, empati, simpati, berbagi, menolong, kerjasama, bersaing, menjalin hubungan dengan orang lain atau biasanya berhubungan dengan kecerdasan.

Kecerdasan merupakan keterampilan berpikir dan kemampuan untuk beradaptasi dan belajar dari pengalaman hidup sehari-hari. Perkembangan kecerdasan mempunyai tujuan berfikir secara reflektif untuk dapat memahami, melakukan inovasi, dapat menemukan berbagai alternatif pemecahan masalah, serta membantu anak mengembangkan sikap dan perilakunya. Gardner (dalam Fadlillah, 2014) mengungkapkan bahwa manusia tidak hanya memiliki satu kecerdasan melainkan sembilan jenis kecerdasan yaitu, kecerdasan matematika, kecerdasan linguistik, kecerdasan musikal, kecerdasan spasial, kecerdasan kinestetik, kecerdasan interpersonal, kecerdasan intrapersonal, kecerdasan natural, dan kecerdasan eksistensial.

Salah satu kecerdasan yang penting distimulasi dalam kaitannya dengan kemampuan anak bersosialisasi, ialah kecerdasan interpersonal. Anak dengan kecerdasan interpersonal memiliki banyak kecakapan, yakni kemampuan berempati (berbagi, menolong dan membantu orang lain), kemampuan mengenali pikiran orang lain, kemampuan berteman, dan menjalin relasi sosial. Untuk penyesuaian diri dengan lingkungan, kecerdasan interpersonal sangat diperlukan dalam membangun hubungan positif dengan orang lain.

Kecerdasan interpersonal anak dapat dilihat dalam kepekaan anak terhadap perasaan teman sebaya, kemampuan memotivasi dan mendorong orang lain, keramahan sikap dan kemampuan bersosialisasi, kecenderungan bekerjasama dengan orang lain dan berbagi, kemampuan menengahi konflik, dan hal-hal lain yang sifatnya berhubungan dengan orang lain. Hal ini didukung oleh beberapa penelitian yang menyebutkan bahwa kecerdasan interpersonal sangat diperlukan dalam setiap kegiatan sehari-hari, baik di sekolah, di rumah, maupun di masyarakat. Berkembangnya kecerdasan interpersonal memudahkan anak untuk menjalin relasi sosial dan tidak mengalami kesulitan untuk bekerjasama dengan orang lain 
(Istanty, 2014). Mengembangkan kecerdasan interpersonal anak merupakan kewajiban pendidik yang perlu dipenuhi, sebab individu adalah makluk sosial, dengan harapan ketika anak dewasa nantinya anak dapat berinteraksi secara baik dengan orang lain dalam lingkup sosial yang berbeda-beda (Martin, 2016). Pada dasarnya setiap anak akan memerlukan bantuan orang lain dan tidak dapat dihindari akan hidup di lingkungan sosial, namun dalam kenyataannya banyak anak yang belum mampu meyesuaikan diri untuk menjalin hubungan positif dengan orang lain (Rahmawati, 2015). Menurut Suyadi (2010:170) kecerdasan interpersonal adalah "kemampuan yang baik membuat yang bersangkutan untuk mempunyai kepekaan hati hati yang tinggi". Kepekaan ini mendorong orang memberikan perhatian yang tinggi pada orang lain, senang membantu teman lainnya, sehingga bisa bersikap empatik tanpa menyinggung apalagi menyakiti perasaan orang lain. Menurut Amstrong (dalam Sholeh, 2016:29) kecerdasan interpersonal adalah "kemampuan memahami dan bekerja sama dengan orang lain". Kecerdasan interpersonal yang menonjol pada anak akan dapat dilihat dari cara berinteraksi yang baik dengan orang lain, pintar menjalin hubungan sosial, serta mampu mengetahui dan menggunakan beragam cara saat berinteraksi. Mampu merasakan perasaan, pikiran, tingkah laku dan harapan orang lain, serta mampu bekerja sama dengan orang lain. Said (2015) mengatakan anak dengan kecerdasan interpersonal memahami proses belajar dengan berinteraksi secara efektif. Guru dapat menyajikan aktivitas pembelajaran yang dilakukan dengan proses interaksi kerja sama dalam sebuah kelompok belajar.

Dari definisi tersebut, maka dapat simpulkan kecerdasan interpersonal adalah kemampuan yang dimiliki seseorang dalam merasakan dan merespon secara tepat suasana hati, dan keinginan orang lain. Sehingga dapat berhubungan dengan orang, berkomunikasi, dan dapat menyesuaikan diri dengan lingkungan dimanapun anak berada. Kecerdasan interpersonal penting dalam kehidupan manusia karena pada dasarnya manusia tidak bisa hidup sendiri. Banyak kegiatan dalam kehidupan yang berkaitan dengan orang lain, begitu juga dengan seorang anak yang membutuhkan dukungan orang-orang disekitarnya.

Menurut Mork (dalam Yaumi, 2012:145) terdapat aspek-aspek penting dari kecerdasan interpersonal adalah:

a) Membaca isyarat sosial, yaitu anak dapat memperhatikan bagaimana orang lain berkomunikasi, memahami komunikasi verbal dan nonverbal yang digunakan dalam berinteraksi (seperti: bersandar, menyentuh lengan, tatapan, tertawa, senyum, dan berbagai komunikasi nonverbal lainnya), memperhatikan keberhasilan atau tidaknya komunikasi untuk menentukan bagaimana harus bertindak.

b) Memberikan empati, yaitu anak dapat memposisikan atau meletakkan diri berada pada perspektif atau posisi orang lain dan menghayati pengalaman orang tersebut, membuat keputusan atau menyelesaikan konflik, mengajukan pertanyaan untuk mengetahui apa sebenarnya yang diinginkan oleh orang tersebut dalam suatu situasi. Membandingkan keinginannya dengan keinginan orang lain, mencari kesamaan agar dapat berkompromi. Hal ini hanya berkembang jika anak dapat memahami ekspresi wajah atau maksud pembicaraan orang lain.

c) Mengontrol emosi, yaitu anak dapat menahan amarah, rasa cemburu, rasa takut, malu, khawatir, cemas, rasa ingin tahu, dan rasa gembira pada saat-saat tertentu. Anak dapat mengekspresikan emosi pada tempatnya, mengetahui kapan saatnya mengungkapkan rasa iba dan kasih sayang, hubungan emosional, atau mengungkapkan emosi yang positif. Dapat membagi senyum, memberi pujian, mencari hal-hal yang disukai pada orang lain, dan mengungkapkan segala pikiran positif secara verbal.

Suroso (2004:22), menyatakan ciri yang menonjol dari kecerdasan interpersonal yaitu, "kemampuan negosiasi tinggi, mampu membaca maksud hati orang lain, mulai berhubungan dengan orang lain, memiliki banyak teman, menikmati kegiatan bersama, mampu berkomunikasi dengan baik, suka bekerja sama, membaca situasi sosial dengan baik". 
Sedangkan Safaria (2005) mengatakan, karakteristik anak yang memiliki kecerdasan interpersonal yang tinggi yaitu:

a) Mampu mengembangkan dan menciptakan serta mempertahankan hubungan sosial secara efektif.

b) Mampu berempati dengan orang lain atau memahami orang lain.

c) Mampu menyadari perubahan situasi sosial, agar dapat menyesuaikan diri secara efektif.

d) Mampu memecahkan masalah yang terjadi dalam hubungan sosial dengan pendekatan, sehingga mencegah munculnya masalah.

e) Memiliki keterampilan komunikasi yang mencakup keterampilan mendengarkan, dan berbicara efektif.

Berdasarkan pendapat di atas, maka dapat disimpulkan anak yang kecerdasan interpersonalnya tinggi memiliki karakteristik dapat membangun dan mengembangkan hubungan yang harmonis dengan orang lain, mampu melakukan kerjasama, mampu berinteraksi dengan orang lain, menyukai kegiatan-kegiatan yang melibatkan aktivitas kelompok serta mampu mengatasi segala konflik yang terjadi dalam kegiatan.

Oleh sebab itu mengembangkan kecerdasan interpersonal sejak usia dini khususnya 5-6 tahun sangat dianjurkan agar kedepannya anak bisa hidup di lingkungan apapun anak bisa membawa dirinya, tidak harus menetap dan bergantung pada satu orang saja, karena manusia adalah makhluk sosial. Begitu pula dengan anak usia dini semakin usianya bertambah memerlukan cara bersosialisasi dan berinteraksi dengan orang lain. Ciri yang akan menonjol pada anak yang memiliki kecerdasan interpersonal ialah kemampuan negosiasi tinggi, memiliki rasa empati, mahir berhubungan dengan orang lain, memiliki banyak teman, mampu berkomunikasi dengan baik, menikmati kegiatan bersama, suka bekerja sama, dan dapat membaca situasi di lingkungan sosial.

Berdasarkan hasil observasi dan wawancara dengan sumber, diperoleh data bahwa TK Gugus I Sukawati kelompok B memiliki permasalahan terhadap cenderung rendahnya kecerdasan interpersonal anak yang menjadikan anak kurang mampu dalam menjalin pertemanan (berkawan), anak tidak mau bergabung dan saling berbagi dengan temantemannya. Hal tersebut disebabkan oleh beberapa faktor yaitu, kurangnya kegiatan yang menstimulasi kecerdasan interpersonal anak, serta kurangnya penerapan metode pembelajaran yang melibatkan anak secara aktif dalam berinteraksi dengan temannya. Melihat dari permasalahan ini maka dibutuhkan upaya yang dapat dilakukan untuk mengembangkan kecerdasan interpersonal anak yaitu, dengan cara menggunakan metode pembelajaran yang dapat menstimulasi kecerdasan interpersonal anak. Metode pembelajaran yang digunakan harus sesuai dengan tujuan yang ingin dicapai dalam kegiatan pembelajaran. Terdapat berbagai macam metode yang dapat digunakan dalam pembelajaran dan salah satunya yaitu metode proyek.

Metode proyek merupakan salah satu cara pemberian pengalaman belajar dengan menghadapkan anak dengan persoalan sehari-hari yang harus dipecahkan secara berkelompok (Ariyani, 2014). Melalui metode ini anak-anak dapat berkolaborasi berkomunikasi dan bertukar pikiran serta dapat meningkatkan motivasi dengan temannya karena pelaksanaan pembelajaran ini secara berkelompok. Hal ini didukung dengan penelitian terdahulu oleh Nurhalimah (2012) peranan metode proyek memberikan kesempatan bagi anak untuk terlibat aktif berinteraksi dengan orang lain dalam berbagai pekerjaan dan tanggungjawab yang dilaksanakan secara kelompok dalam rangka mencapai tujuan bersama. Dengan demikian anak akan terlalih secara alami mau bekerja dan secara produktif menemukan berbagi pengetahuan, dapat berinteraksi dengan teman sebayanya, serta mengembangkan keterampilan menjalani kehidupan sehari-hari. 
Rusman (2017:397) menyatakan, metode proyek merupakan "metode belajar yang menggunakan masalah sebagai langkah awal dalam mengumpulkan dan mengintegrasikan pengetahuan baru berdasarkan pengalamannya dalam beraktivitas secara nyata". Penggunaan masalah pada metode ini dapat meningkatkan keterampilan yang telah dimiliki dan memberikan peluang bagi anak untuk mengasah kecerdasannya. Menurut Fathurrohman (2015:118) metode proyek adalah "model pembelajaran yang melibatkan suatu masalah dalam proses pembelajaran perseorangan atau kelompok dan dilaksanakan dalam jangka waktu tertentu". Dalam kehidupan sehari-hari pasti akan ada muncul suatu permasalahan, tak terkecuali dalam kehidupan anak usia dini. Terlibatnya anak dalam suatu masalah dapat mengajarkan anak untuk bisa menyelesaikan masalah maupun tantangan yang dihadapinya sehingga anak juga memperoleh pembelajaran yang baik. Metode proyek adalah suatu cara mengajar yang memberikan kesempatan kepada anak didik untuk menggunakan alam sekitar atau kegiatan sehari-hari anak sebagai bahan pelajarannya melalui berbagai kegiatan (Susanto, 2017).

Pembelajaran proyek merupakan model pembelajaran yang menggunakan proyek/kegiatan sebagai media. Menurut Klein, et al (dalam Fathurrohman, 2015:123) pembelajaran metode proyek yang efektif harus memiliki karakteristik sebagai berikut:

a) Membimbing anak dalam mengeluarkan ide dan pertanyaan-pertanyaan yang berkaitan dengan pekerjaannya.

b) Mementingkan pada proses dalam kegiatan tersebut.

c) Proyek diberikan sesuai dengan kebutuhan dan minat anak.

d) Mendorong anak untuk menjadi mandiri dalam mengerjakan tugas dan mengkomunikasikan hasil pekerjaannya.

e) Dapat melatih anak kreatif, berpikir kritis dan kemampuan mengelola informasi.

f) Dapat melatih anak dalam menyimpulkan hasil pekerjaannya.

g) Berhubungan dengan permasalahan-permasalahan di kehidupan sehari-hari.

Dapat ditafsirkan metode proyek memiliki peluang untuk menstimulasi kecerdasan interpersonal. Karena metode proyek merupakan model pembelajaran yang melibatkan anak secara aktif dalam mencapai tujuan pembelajaran untuk dapat menghasilkan berbagai kemampuan, tidak hanya pengetahuan atau masalah teknis, tetapi juga keterampilan seperti mengatasi informasi, hubungan antar manusia yang dapat dirangsang melalui bekerja sama memecahkan masalah. Metode proyek diharapkan mampu mengembangkan kecerdasan interpersonal anak. Sebab hubungan antar manusia merupakan salah satu tuntutan hidup yang harus dihadapi dalam kehidupan sehari-hari.

Dalam menerapankan metode proyek dengan kurikulum PAUD 2013 (K-13) disarankan agar pembelajaran digunakan pendekatan saintifik yang menekankan pada aspek aktivitas langsung. Aktivitas langsung dalam membangun cara berpikir agar anak memiliki kemampuan menalar yang diperoleh melalui proses mengamati sampai pada mengkomunikasikan hasil pikirannya. Pendekatan pembelajaran yang tepat pada anak akan menentukan keberhasilan anak dalam mencapai perkembangan yang optimal sesuai dengan karakteristik, minat, dan potensinya. Permendikbud (No. 146, tahun 2014) menyatakan bahwa "pendekatan pembelajaran saintifik mencakup rangkaian proses mengamati, menanya, mengumpulkan informasi, menalar, dan mengomunikasikannya". Pendekatan saintifik mendorong dan menginspirasi anak berpikir secara kreatif, kritis, analisis, dan tepat dalam mengidentifikasi, memahami, serta memecahkan masalah dalam melihat perbedaan, kesamaan, dan tautan satu sama lain dari materi pembelajaran sehingga dapat mengembangkan pola berpikir yang rasional dan objektif dalam merespon.

Berdasarkan uraian tersebut, maka dilakukan penelitian eksperimen yang berjudul "Pengaruh Metode Proyek Berbasis Pendekatan Saintifik Terhadap Kecerdasan Interpersonal Anak Kelompok B di TK Gugus 1 Sukawati Tahun Ajaran 2018/2019”. 
Berdasarkan latar belakang yang telah dipaparkan tersebut, maka identifikasi masalah pada penelitian ini adalah, masih rendahnya kecerdasan interpersonal anak, yang ditunjukkan dengan prilaku menyendiri, mementingkan diri sendiri, dan memilih-milih dalam berteman masih mendominasi pada anak. kurangnya stimulasi, kegiatan yang dapat melibatkan anak secara aktif dalam berinteraksi dengan kegiatan kelompok. Metode proyek berbasis pendekatan saintifik masih jarang digunakan dalam pembelajaran di kelas.

Rumusan masalah dalam penelitian ini adalah apakah terdapat pengaruh yang signifikan metode proyek berbasis pendekatan saintifik terhadap kecerdasan interpersonal anak kelompok B di TK Gugus I Sukawati Tahun Ajaran 2018/2019.

Berdasarkan latar belakang dan rumusan masalah tersebut, maka tujuan penelitian yang ingin dicapai dalam penelitian ini adalah untuk mengetahui pengaruh yang signifikan metode proyek berbasis pendekatan saintifik terhadap kecerdasan interpersonal anak kelompok B di TK Gugus I Sukawati Tahun Ajaran 2018/2019.

\section{Tipe Artikel}

Hasil penelitian sebelumnya yang relevan dengan model pembelajaran yang diterapkan dalam penelitian ini yaitu, penelitian yang dilakukan oleh Mujahidah (2014). Penelitian ini dilatar belakangi karena pentingnya kecerdasan interpersonal dalam melakukan aktivitas pembelajaran bermakna untuk mengajak anak bermain, dan mengembangkan kemampuan dalam bersosialisasi, dan berempati. Kurangnya pengalaman secara langsung bagi anak dalam pembelajaran, maka akan menghambat perkembangan anak dalam mempelajari ilmu. Tujuan umum penelitian ini adalah untuk mengetahui permasalahan dalam kecerdasan interpersonal anak supaya lebih ditingkatkan pada Kelompok A RA AL Ikhlas Subah Batang yang berjumlah 20 siswa. Metode yang dipakai dalam penelitian ini adalah Penelitian Tindakan Kelas dengan menggunakan metode observasi dan dokumentasi. Data yang diperoleh dipengamatan dianalisis secara deskripsi kualitatif dengan mengolah data dari hasil pengamatan dalam kegiatan dan evaluasi kecerdasan interpersonal anak melalui metode proyek dalam bentuk prosentase. Hasil penelitian ini diperoleh bahwa hasil belajar kelompok A pada awalnya $35 \%$ disebabkan karena metode yang digunakan kurang tepat. Setelah diadakan perbaikan tindakan dengan mengguanakan kegiatan menghias keranjang sampah dengan hasil pada siklus I diperoleh sebesar $75 \%$ sedangkan pada siklus II kegiatan menghias tempat pensil deperoleh sekitar $85 \%$. Hal ini menunjukkan adanya peningkatan kecerdasan interpersonal pada kelompok A RA AL Ikhlas Subah Batang.

Penelitian kedua yaitu penelitian yang dilakukan oleh Maliah (2015). Penelitian ini bertujuan untuk meningkatkan kecerdasan interpersonal anak melalui metode proyek pada anak kelompok $\mathrm{B}$. Jenis penelitian yang digunakan adalah penelitian tindakan kelas secara kolaboratif. Metode pengumpulan data yang digunakan adalah metode observasi dan dokumentasi. Instrumen penelitian yang digunakan adalah lembar observasi. Teknik analisis data menggunakan teknik analisis deskriptif kuantitatif. Penelitian ini dilaksanakan dua siklus dengan empat kali pertemuan disetiap siklusnya dengan waktu kurang lebih 90 menit dalam kegiatan pembelajaran inti. Peningkatan kecerdasan interpersonal anak dapat dilihat dari perbandingan hasil observasi yang telah dilakukan pada Pra tindakan, siklus I, siklus II yang hasilnya mengalami peningkatan. Pada siklus I dengan persentase $45,46 \%$, sedangkan siklus II mengalami peningkatan dengan persentase 90,91\%. Dengan demikian, proses pembelajaran melalui metode proyek dapat dikatakan berhasil karena $85 \%$ dari 11 anak yaitu 10 anak di kelas B2 TK ABA Plus Al Firdaus Mancasan, Sleman, Daerah Istimewa Yogyakarta, telah mencapai indicator peningkatan kecerdasan interpersonal pada kriteria Berkembang Sangat Baik (BSB). 


\section{METODE}

Rancangan dari penelitian ini menggunakan penelitian eksperimen semu (quasi eksperimen), dengan menggunakan rancangan Nonequivalent Control Group Desain

\begin{tabular}{|lll|}
\hline $\mathrm{O}_{1}$ & $\mathrm{X}$ & $\mathrm{O}_{2}$ \\
\hline $\mathrm{O}_{3}$ & & $\mathrm{O}_{4}$ \\
\hline
\end{tabular}

Keterangan:

(Sugiyono, 2017:116)

$\mathrm{O}_{1}=$ Pre-test kelompok eksperimen

$\mathrm{O}_{2}=$ Post-test kelompok eksperimen

$\mathrm{O}_{3}=$ Pre-test kelompok kontrol

$\mathrm{O}_{4}=$ Post-test kelompok kontrol

$\mathrm{X}=$ Perlakuan dengan metode proyek pada

kelompok eksperimen

Pemberian treatment berupa perlakuan metode proyek berbasis saintifik dilakukan di kelompok eksperimen, sedangkan di kelompok kontrol dilaksanakan pembelajaran yaitu metode konvensional. Pre-test dilakukan hanya untuk mengetahui kesetaraan kelompok dengan menganalisis nilai pre-test yang diberikan kepada anak yang mencakup kemampuan motorik halus anak. Post-test dilakukan pada akhir penelitian setelah diberikan perlakuan untuk mendapatkan hasil kecerdasan interpersonal anak di kelompok eksperimen dan kelompok kontrol. Dalam penelitian ini yang diperhitungkan hanya skor post-test saja tanpa memperhitungkan skor pre-test. Hal tersebut dikarenakan pada penelitian ini bertujuan untuk mengetahui pengaruh bukan peningkatan kecerdasan interpersonal anak pada kedua kelompok.

Populasi dalam penelitian ini adalah seluruh anak kelompok B di TK Gugus I Sukawati. Pupulasi menurut Sugiyono (2016:117) merupakan wilayah generalisasi yang terdiri atas objek atau subjek yang mempunyai kualitas dan karakteristik tertentu yang ditetapkan oleh peneliti untuk dipelajari kemudian ditarik kesimpulannya".

Data yang diperlukan dalam penelitian ini adalah data terkait kecerdasan interpersonal anak, dalam penelitian ini data diperoleh melalui teknik observasi. Langkah ini sangat penting karena data yang dikumpulkan nanti akan digunakan dalam menguji hipotesis. Maka, teknik pengumpulan data harus disesuaikan dengan data yang diperlukan.

Instrumen penelitian dibuat dalam bentuk kisi-kisi kecerdasan interpersonal anak, tetapi sebelum menerapkan kisi-kisi instrument dilakukan uji coba instrumen yaitu uji validitas isi. Validitas isi yang menyangkut dengan isi dan format instrumen. Validitas isi berkenaan dengan ketepatan instrumen dalam suatu variabel yang akan diukur, serta ketepatan format instrumen. Validitas isi terlebih dahulu akan diuji oleh judgement (dosen penguji) dan kepala TK di Tempat penelitian.

Untuk menganalisis data kecerdasan interpersonal anak yang bersifat kuantitatif digunakan statistik uji t. Sebelum dilakukan uji hipotesis terlebih dahulu dilakukan uji prasyarat analisis yaitu uji normalitas sebaran data yang dimaksud untuk mengetahui dapat atau tidaknya melakukan uji hipotesis untuk mengetahui sebaran data skor nilai kecerdasan 
interpersonal anak berdistribusi normal atau tidak sehingga dapat menentukan teknik analisis datanya. Kriteria pengujian adalah uji Chi-Kuadrat $\left(X^{2}\right)$ pada taraf signifikansi $5 \%$ dan derajat kebebasan $(\mathrm{dk})=\mathrm{n}-1$. Apabila $\mathrm{X}^{2}{ }_{\text {hit }}<\mathrm{X}^{2}$ tabel maka data berdistribusi normal. Untuk mengetahui data tersebut homogen dapat digunakan uji $F$ dengan kriteria pengujian jika $F_{\text {hitung }}<F_{\text {tabel }}$ maka sampel homogen. Pada taraf signifikan $5 \%$ dengan pengujian derajat kebebasan untuk pembilang $n_{1}-1$ dan derajat kebebasan untuk penyebut $n_{2}-1$. Sehingga, apa bila $F_{\text {hitung }}<F_{\text {tabel }}$ maka varians antara kelompok ekperimen dengan kelompok kontrol homogen.

Hipotesis yang akan diuji adalah: Untuk membuktikan Ho ditolak, maka harga thitung $>$ $t_{\text {tabel, }}$ maka $\mathrm{H}_{\circ}$ ditolak dan $\mathrm{H}_{\mathrm{a}}$ diterima. Pada taraf signifikansi $5 \%$ dengan derajat kebebasan (dk $=\mathrm{n} 1+\mathrm{n} 2-2)$.

\section{HASIL DAN PEMBAHASAN}

Pada penelitian ini yang ditetapkan sebagai kelompok eksperimen adalah kelompok B2 TK Ana Kumara yang berjumlah 28 anak, sedangkan yang menjadi kelompok kontrol adalah kelompok B1 TK Kumara Santhi Guwang yang berjumlah 27 anak. Pada kelompok eksperimen diberikan treatment berupa pembelajaran menggunakan metode proyek berbasis pendekatan saintifik, sedangkan pada kelompok kontrol diberikan perlakuan berupa pembelajaran konvensional atau pembelajaran sehari-hari. Sebelum diberikan perlakuan pada kelompok ekperimen dan kelompok kontrol, maka masing-masing kelompok diberikan pre-test yang bertujuan untuk melakukan penyetaraan kelompok. Perlakuan diberikan sebanyak 6 kali pada kelompok ekperimen dan kelompok kontrol. Setelah itu dilanjutkan dengan pemberian post-test.

Teknik yang digunakan dalam pengumpulan data adalah non test. Non test berupa observasi menggunakan lembar observasi kecerdasan interpersonal. Data yang diperoleh dalam penelitian ini menunjukan adanya pengaruh metode proyek berbasis pendekatan saintifik terhadap kecerdasan interpersonal pada anak kelompok B di TK Gugus I Sukawati Tahun Ajaran 2018/2019. Pengaruh tersebut ditunjukan oleh nilai rata-rata post-test pada kelompok eksperimen $=84,31$ dan kelompok kontrol=71.84. Berdasarkan uji hipotesis diperoleh $\mathrm{T}_{\text {hitung }}=5,97$ sedangkan taraf signifikansi $5 \%$ dengan $\mathrm{dk}=53$ diperoleh nilai $T_{\text {tabel }}=2,000$ sehingga $t_{\text {hitung }}>t_{\text {tabel }}$. Dengan demikian, $H_{0}$ ditolak.

Uji normalitas sebaran data kecerdasan interpersonal dilakukan di kelompok eksperimen dan kelompok kontrol. Berikut ini merupakan rekapitulasi hasil uji normalitas sebaran data kelompok eksperimen dan kelompok kontrol disajikan pada tabel 1. berikut ini.

Tabel 1. Hasil Uji Normalitas Sebaran Data

\begin{tabular}{lcccc}
\hline \multicolumn{1}{c}{ Hasil Analisis } & $\mathrm{N}$ & $\mathrm{X}^{2}$ hitung & $\mathrm{X}^{2}$ tabel & Keterangan \\
\hline $\begin{array}{l}\text { Kelompok B2 TK } \\
\text { Ana Kumara }\end{array}$ & 28 & 5,01 & 11,07 & $\begin{array}{c}\text { Berdistribusi } \\
\text { normal }\end{array}$ \\
$\begin{array}{l}\text { Kelompok B1 TK } \\
\text { Kumara Santhi }\end{array}$ & 27 & 4,87 & 11,07 & $\begin{array}{c}\text { Berdistribusi } \\
\text { normal }\end{array}$ \\
\hline
\end{tabular}

Berdasarkan perhitungan hasil uji normalitas sebaran data kelompok B2 TK Ana Kumara dengan taraf signifikansi $5 \%$ dan dk $=5$ adalah $X^{2}{ }_{\text {hit }}=5,01$ dan $X_{\text {tabel }}^{2}=11,07$, karena $X^{2}$ hit $<$ $\mathrm{X}_{\text {tabel }}^{2}$ maka data berdistribusi normal. Hal ini berarti skor sebaran data kecerdasan interpersonal anak kelompok B2 di TK Ana Kumara yang dibelajarkan menggunakan metode proyek berbasis pendekatan saintifik berdistribusi normal. Sedangkan, berdasarkan perhitungan hasil uji normalitas sebaran data nilai kelompok B1 TK Kumara Santhi dengan taraf sifnifikansi $5 \%$ dan $\mathrm{dk}=5$ adalah $\mathrm{X}^{2}{ }_{\text {hit }}=4,87$ dan $\mathrm{X}^{2}$ tabel $=11,07$, karena $\mathrm{X}^{2}{ }_{\text {hit }}<\mathrm{X}^{2}$ tabel 
maka data berdistribusi normal. Hal ini berarti skor sebaran data kecerdasan interpersonal anak kelompok B di TK Kumara Santhi yang dibelajarkan menggunakan pembelajaran konvensional berdistribusi normal.

Selanjutnya dilakukan uji homogenitas varians berdasarkan data kecerdasan interpersonal anak yang dibelajarkan melalui metode proyek berbasis pendekatan saintifik dan yang tidak dibelajarkan metode proyek berbasis pendekatan saintifik. Jumlah kelompok eksperimen 28 anak dan kelompok kontrol 27 anak, untuk menentukan homogenitas varians digunakan uji $\mathrm{F}$, berikut ini akan disajikan pada tabel 2 .

Tabel 2. Uji Homogenitas Varians Kelompok Eksperimen dan Kontrol

\begin{tabular}{lcccccc}
\hline \multicolumn{1}{c}{ Sampel } & Mean & SD & Varians & $F_{\text {hitung }}$ & $F_{\text {tabel }}$ & Kesimpulan \\
\hline $\begin{array}{l}\text { Kelompok } \\
\text { Eksperimen }\end{array}$ & 84,31 & 8,73 & 76,30 & 1,59 & 1,92 & Homogen \\
$\begin{array}{l}\text { Kelompok } \\
\text { Kontrol }\end{array}$ & 71,84 & 6,92 & 47,86 & & & \\
\hline
\end{tabular}

Berdasarkan tabel 2. Nilai $F_{\text {tabel }}$ pada taraf signifikansi $5 \%$ dengan derajat kebebasan ( $d k$ pembilang $=27$ dan dk penyebut $=26)=1,92$ dan hasil analisis $F_{\text {hitung }}<F_{\text {tabel }}$ maka varians antara kelompok eksperimen dengan kelompok kontrol homogen.

Berdasarkan hasil uji normalitas sebaran data dan uji homogenitas varians diperoleh bahwa data kedua kelompok berdistribusi normal dan varians kedua kelompok homogen. Berdasarkan data tersebut maka uji statistik yang digunakan dalam penelitian ini adalah uji beda mean (uji t). Hasil perhitungan uji hipotesis disajikan dalam tabel 3 berikut ini.

Tabel 3. Uji Hipotesis Kelompok Eksperimen dan Kelompok Kontrol

\begin{tabular}{lccccccc}
\hline \multicolumn{1}{c}{ Sampel } & $\mathrm{N}$ & Dk & Mean & Varians & $t_{\text {hitung }}$ & $t_{\text {tabel }}$ & Kesimpulan \\
\hline $\begin{array}{l}\text { Kelompok } \\
\text { Eksperimen }\end{array}$ & 28 & 53 & 84,31 & 76,30 & 5,97 & 2,000 & $\mathrm{H}_{\circ}$ ditolak \\
$\begin{array}{l}\text { Kelompok } \\
\text { Kontrol }\end{array}$ & 27 & & 71,84 & 47,86 & & & \\
\hline
\end{tabular}

Berdasarkan tabel 3 maka diperoleh thitung $=5,97$ sedangkan pada taraf signifikansi $5 \%$ diperoleh nilai ttabel $=2,000$ sehingga $t_{\text {hitung }}>t_{\text {tabel }}$. Berdasarkan hasil tersebut, maka dapat disimpulkan bahwa Ho menyatakan "tidak terdapat perbedaan yang signifikan kecerdasan interpersonal antara kelompok anak yang dibelajarkan menggunakan metode proyek berbasis pendekatan saintifik dengan kelompok anak yang tidak dibelajarkan menggunakan metode proyek berbasis pendekatan saintifik pada anak kelompok B di TK Gugus I Sukawati Tahun Ajaran 2018/2019", ditolak.

Dengan demikian, maka terdapat pengaruh meode proyek berbasis pendekatan saintifik terhadap kecerdasan interpersonal anak kelompok B TK Gugus I Sukawati Tahun Ajaran $2018 / 2019$.

Berdasarkan hasil mean atau rerata nilai kecerdasan interpersonal anak sebelum dibelajarkan menggunakan metode proyek berbasis pendekatan saintifik yaitu $X=47,99$, sedangkan nilai mean atau rerata nilai kecerdasan interpersonal setelah dibelajarkan menggunakan metode proyek berbasis pendekatan saintifik, yaitu $X=84,31$. Hasil data tersebut menunjukkan bahwa, kecerdasan interpersonal anak sesudah dibelajarkan menggunakan metode proyek berbasis pendekatan saitifik memiliki rata-rata yang lebih tinggi dibandingkan dengan hasil sebelum dibelajarkan menggunakan metode proyek berbasis pendekatan saintifik. Hasil uji normalitas data 
pre-test, diperoleh Chi Kuadrat hitung $\left(X^{2}\right.$ hitung $\left.=4,26\right)$ kemudian nilai tersebut dibandingkan dengan Chi Kuadrat tabel $\left(X^{2}\right.$ tabel $\left.=11.07\right)$. Hal ini menunjukkan bahwa $X^{2}$ hitung $\leq X^{2}$ tabel berarti data pretest kecerdasan interpersonal berdistribusi normal. Berdasarkan hasil uji normalitas data posttest, diperoleh Chi Kuadrat hitung $\left(X^{2}\right.$ hitung $\left.=5,01\right)$ kemudian nilai tersebut dibandingkan dengan Chi Kuadrat tabel $\left(X^{2}\right.$ tabel $\left.=11.07\right)$. Hal ini menunjukkan bahwa $X^{2}$ hitung $\leq X^{2}$ tabel berarti data kecerdasan interpersonal anak data post-test berdistribusi normal.

Tabel 4.

Data Kecerdasan Interpersonal Anak Kelompok Eksperimen dan Kelompok Kontrol

\begin{tabular}{lcc}
\hline \multicolumn{1}{c}{ Hasil Analisis } & Kelompok Eksperimen & Kelompok Kontrol \\
Mean & 84,31 & 71,84 \\
Standar Deviasi & 8,73 & 6,92 \\
Varians & 76,30 & 47,86 \\
Skor Maksimum & 97,92 & 83,33 \\
Skor Minimum & 66,67 & 60,42 \\
\hline
\end{tabular}

\section{PENUTUP}

Berdasarkan hasil penelitian dan pembahasan, maka dapat ditarik simpulan bahwa metode proyek berbasis pendekatan saintifik terhadap kecerdasan interpersonal anak kelompok B di TK Gugus I Sukawati, hal ini terbukti dari hasil rata-rata kelompok yang dibelajarkan dengan menggunakan metode proyek berbasis pendekatan saintifik (kelompok ekperimen) diperoleh rata-rata sebesar 84,31 , sedangkan pada kelompok yang dibelajarkan dengan pembelajaran konvensional (kelompok kontrol) diperoleh rata-rata sebesar 71,84. Rerata kecerdasan interpersonal pada anak yang dibelajarkan melalui metode proyek berbasis saintifik lebih tinggi dibanding dengan anak yang dibelajarkan menggunakan metode konvensional. Berdasarkan hasil analisis menggunakan uji-t diperoleh thitung 5,97 dengan taraf signifikan $5 \%$ dan ( $d k=53)$, maka diperoleh $t_{\text {tabel }} 2.003$ sehingga $t_{\text {hitung }} 5,97 \geq t_{\text {tabel }} 2.003$, sehingga terdapat pengaruh metode proyek terhadap kecerdasan interpersonal anak kelompok B di TK Gugus I Sukawati Tahun Ajaran 2018/2019.

Berdasarkan simpulan dari penelitian ini, maka hasil penelitian ini dapat dipakai sebagai kajian penelitian relevan yang bermanfaat untuk meneliti tentang pengaruh metode proyek berbasis pendekatan saintifik terhadap kecerdasan interpersonal anak.

\section{DAFTAR PUSTAKA}

Ariyani, Eka. (2014). "Penerapan Metode Proyek Untuk Mengembangkan Kognitif Anak dalam Mengenal Konsep Bentuk, Warna, Ukuan dan Pola di Kelompok B2 Pendidikan Anak Usia Dini Pertiwi 1 Kota Bengkulu". Tersedia pada http://repository.unib.ac.id/8645/ (diakses tanggal 13 Desember 2018)

Fadlillah, M. (2014). Desain Pembelajaran PAUD (Cetakan II). Jogjakarta: AR-RUZZ MEDIA.

Fathurrohman, M. (2015). Model-model Pembelajaran Inovatif Alternatif Desain Pembelajaran yang Menyenangkan (Cetakan I). Jogjakarta: AR-RUZZ MEDIA. 
Istanty, Dewi, dkk. (2014). "Analisis Kecerdasan Interpersonal Pada Anak Usia 5-6 Tahun di Taman Kanak-kanak Darul Khair Pontianak", 1-10. Tersedia pada http://jurnal.untan.ac.id/index.php/jpdpb/article/view/6983 (diakses tanggal 14 Maret 2018)

Lestari, Shintia Ayu. (2017). "Pengaruh Penggunaan Metode Proyek Terhadap Pengembangan Kemampuan Mengenal Konsep Bilangan Anak 5-6 Tahun di TK Citra melati Bandar Lampung Tahun Ajaran 2016/2017". Tersedia Pada http://digilib.unila.ac.id/27103/3/SKRIPSI\%20TANPA\%20BAB\%20PEMBAHASAN.pdf (diakses tanggal 13 Desember 2018)

Maliah, Nadhiroh Aminul. (2015). "Meningkatkan Kecerdasan Interpersonal melalui Metode Proyek Pada Anak Kelompok B2 TK ABA Plus Al Firdaus Mancasan, Pandowoharjo, Sleman, Daerah Istimewa Yogyakarta". Pendidikan Guru Pendidikan Anak Usia Dini, volume8 Tahun Ke-4. Tersedia pada https://eprints.uny.ac.id/27689/ (diakses tanggal 17 Januari 2019)

Martin. (2016). "Analisis Kecerdasan Interpersonal Anak Usia Dini dan Implementasinya dalam Bimbingan dan Konseling". Sosial Horizon : Jurnal Pendidikan Sosial, volum 3, no.2, 243257. Tersedia pada http://journal.ikippgriptk.ac.id/index.php/sosial/article/view/368 (diakses tanggal 14 maret 2018)

Mujahidah, Ulfatul, dan Ellya Rakhmawati. (2014). "Upaya Meningkatkan Kecerdasan Interpersonal Anak Melalui Metode Proyek Pada Kelompok A RA AL Ikhlas Kecamatan Subah Kabupaten Batang Tahun 2013/2014". Universitas PGRI, 110-127. Tersedia pada http://journal.upgris.ac.id/index.php/paudia/article/viewFile/1690/1404_(diakses tanggal 14 Maret 2018)

Nurhalimah, Vika. (2012). "Pengaruh Metode Proyek Terhadap Kemampuan Kerjasama Anak Usia Dini kelompok B di RA Perwanida 03 mojo Andong Boyolali Tahun Pelajaran 2011/2012". Tersedia pada http://eprints.ums.ac.id/19223/ (diakses tanggal 17 Februari 2019)

Nurjannah. (2017). "Mengembangkan Kecerdasan Sosial Emosional Anak Usia Dini Melalui Keteladanan". HISBAH: Jurnal Bimbingan Konseling Dan Dakwah Islam, 14, No. 1, 50-61. Tersedia pada http://ejournal.uin-suka.ac.id/dakwah/hisbah/article/view/141-05 (diakses tanggal 8 Maret 2018)

Permendikbud. (2014). Peraturan Mentri Pendidikan Dan Kebudayaan Republik Indonesia No. 146 Tahun 2014 Tentang Kurikulum 2013 Pendidikan Anak Usia Dini. Jakarta: Kemendikbud.

Rahmawati, Candra Wikan. (2015). "Identifikasi Kecerdasan Interpersonal Anak Usia 4-5 Tahun di TK Gugus Sido Mukti Kecamatan Mantrijeron Kota Yogyakarta". Jurnal Pendidikan Anak Usia Dini, Edisi $\quad 6.00$ Tersedia pada http://journal.student.uny.ac.id/ojs/index.php/pgpaud/article/viewFile/352/319 (diakses tanggal 14 Maret 2018)

Rusman. (2017). Belajar dan Pembelajaran Berorientasi Standar Proses Pendidik (Pertama, C). 
Jakarta: Kencana.

Said, Alamsyah, dan A. B. (2015). 95 Strategi Mengajar Multiple Intelligences Mengajar Sesuai Kerja Otak dan Gaya Belajar Siswa (Edisi I). Jakarta: Kencana.

Sholeh, Khabib, D. (2016). Kecerdasan Majemuk Berorientasi pada Partisipasi Peserta Didik (Cetakan I). Yogyakarta: Pustaka Pelajar.

Sugiyono. (2017). Metode Penelitian Pendidikan (Pendekatan Kuantitatif, Kualitatif, dan R\&D) (Cetakan ke). Bandung: Alfabeta.

Suroso. (2004). Smart Brain, Metode Menghafal Cepat dan Meningkatkan Ketajaman Memori (Cetakan I). Surabaya: SIC.

Susanto, A. (2017). Pendidikan Anak Usia Dini (konsep dan Teori) (Cetakan I). Jakarta: PT Bumi Aksara.

Suyadi. (2010). Psikologi Belajar PAUD (Cetakan I). Yogyakarta: Pedagogia.

Yaumi, M. (2012). Pembelajaran Berbasis Multiple Intelligences (Cetakan I). Jakarta: PT. Dian Rakyat. 